\title{
Hubungan Kepadatan Larva Aedes spp. dengan Kejadian Demam Berdarah Dengue di Kelurahan Lubuk Buaya Kecamatan Koto Tangah Kota Padang
}

\author{
Indah Permata Sari ${ }^{1}$, Adrial $^{2}$, Eka Nofita ${ }^{3}$
}

\begin{abstract}
Abstrak
Kelurahan Lubuk Buaya merupakan daerah yang paling banyak terjadi kasus Demam Berdarah Dengue (DBD) pada tahun 2012 dan 2013 yaitu sebanyak 48 dan 36 kasus. Tingginya angka kejadian DBD ini dipengaruhi oleh kepadatan larva Aedes spp. yang terdapat di wilayah tersebut.Tujuan penelitian ini adalah mengetahui hubungan kepadatan larva Aedes spp. dengan kejadian DBD di Kelurahan Lubuk Buaya Kecamatan Koto Tangah Kota Padang. Penelitian ini merupakan studi analitik dengan pendekatan kasus kontrol.Penelitian ini dilakukan dengan jumlah sampel sebanyak 50 orang. Sampel diambil dengan metode Total Sampling untuk kelompok kasus dan multistage random sampling untuk kelompok kontrol. Data disajikan dalam bentuk tabel distribusi frekuensi dan dianalisis statistik dengan uji chi-square dengan derajat kepercayaan 95\%. Dari 50 subyek penelitian, kelompok kasus yang memiliki kepadatan larva ringan 8 orang $(32,0 \%)$ dan kepadatan larva berat 17 orang $(68,0 \%)$, sedangkan kelompok kontrol yang memiliki kepadatan larva ringan 16 orang (64,0\%) dan kepadatan larva berat 9 orang (36,0\%). Uji chi square menunjukkan terdapat hubungan yang bermakna $(P<0,05)$ antara kepadatan larva Aedes spp. dengan kejadian DBD di Kelurahan Lubuk Buaya Kecamatan Koto Tangah Kota Padang.
\end{abstract}

Kata Kunci: kepadatan larva aedes spp, kejadian DBD

\begin{abstract}
Lubuk Buaya is the most common area of Demam Berdarah Dengue (DBD) cases in 2012 and 2013 with 48 cases and 36 cases. The incident of $D B D$ is high because it is influenced by density of larvae Aedes spp. in that area. The objective of this study was to discover the relationship between density of larvae Aedes spp. with incident DBD in Lubuk Buaya Village Koto Tangah Subdistrict Padang City. The type of research utilized is an analitic with case control study design. The research was held with 50 samples. The samples were taken with the Total Sampling test and Multistage Random Sampling test. Data are presented in distribution table and analyzed statistically with Chi Square test with credibility level 95\%. From 50 samples, cases group who has the low density is 8 (32,0\%) and the high density is 17 (68,0\%), While in controls group who has the low density is 16 (64,0\%) and high density 9 (36,0\%). Chi square test shows the meaningful relationship $(P<0,05)$ between density of larvae Aedes spp. with incident of $D B D$ in Lubuk Buaya Village Koto Tangah Subdistrict Padang City.
\end{abstract}

Keyword: density of larvae aedes spp., incident of $D B D$

Affiliasi penulis: 1. Prodi Profesi Dokter FK Unand, 2. Bagian Parasitologi FK Unand, 3. Bagian Parasitologi FK Unand

Korespondensi: Indah Permata Sari, Email:

indah_permata078@yahoo.com, Telp:085263903620

\section{PENDAHULUAN}

Penyakit DBD adalah penyakit menular yang disebabkan oleh virus dengue.Virus Dengue termasuk dalam golongan Flavivirus, family Togaviridae.Ada 
empat serotipe virus dengue yaitu D-1, D-2, D-3, dan D-4.Di Indonesia dilaporkan ada 3 jenis nyamuk Aedes sebagai vektor DBD yaitu Ae.aegypti, Ae.albopictus, Ae. Scutellaris, tetapi sampai saat ini baru Ae.aegypti yang dianggap sebagai vektor utama dan Ae. albopictus debagai vektor sekunder. ${ }^{1}$

World Health Organization (WHO) mencatat negara Indonesia sebagai negara dengan kasus DBD tertinggi di Asia Tenggara. ${ }^{2}$ Provinsi Sumatera Barat memiliki angka kasus DBD yang masih cukup tinggi. Pada tahun 2012, Incidence Rate (IR) DBD di Sumatera Barat 66,8/100.000 penduduk. Kota Padang menempati urutan tertinggi angka kejadian DBD dengan IR 194,0/100.000 penduduk. ${ }^{3}$ Berdasarkan data dari Dinas Kesehatan Kota Padang pada tahun 2012 wilayah kerja Puskesmas Lubuk Buaya memiliki angka kejadian DBD tertinggi di Kota Padang yaitu sebanyak 203 kasus, dari 6 kelurahan yang termasuk ke dalam wilayah kerja Puskesmas Lubuk Buaya yang memiliki angka kejadian DBD tertinggi adalah Kelurahan Lubuk Buaya yaitu sebanyak 48 kasus, sedangkan pada tahun 2013 Puskesmas Lubuk Buaya menempati urutan kedua kasus terbanyak DBD di Kota Padang yaitu 122 kasus setelah Puskesmas Belimbing dengan jumlah kasus 127 dan Kelurahan Lubuk Buaya masih menduduki posisi tertinggi yaitu 36 kasus. $^{4}$

Tingginya angka kejadian DBD ini dipengaruhi oleh nyamuk Aedes spp. sebagai vektornya.Ae.aegypti suka bertelur di air jernih yang tidak berpengaruh langsung dengan tanah dan lebih menyukai kontainer yang di dalam rumah dari pada di luar rumah. Tempat beristirahat yang disenangi nyamuk ini adalah tempat-tempat yang lembab dan kurang terang seperti kamar mandi, dapur dan WC.Di dalam rumah nyamuk ini beristirahat di baju-baju yang digantung, kelambu dan tirai. Sedangkan di luar rumah nyamuk ini beristirahat pada tanaman-tanaman yang ada di luar rumah. ${ }^{5}$

Usaha untuk mengatasi masalah penyakit DBD yaitu mencari cara diagnosis yang cepat, tepat dan akurat, cara terapi spesifik (kausal) serta pengembangan vaksin untuk pencegahan sudah banyak dilakukan, tetapi sampai saat ini hasilnya belum memuaskan. Alternatif yang paling memberi harapan untuk pemberantasan penyakit ini adalah dengan mengendalikan kepadatan populasi vektornya. ${ }^{6}$

Pengendalian vektor DBD yang paling efektif adalah dengan memutuskan mata rantai penularannya. Pengendalian vektor DBD hampir di semua Negara dan daerah endemis tidak tepat sasaran, tidak berkesinambungan, dan belum mampu memutus rantai penularan. Hal ini disebabkan karena metode yang diterapkan belum mengacu kepada data/informasi tentang vektor, disamping itu masih mengandalkan penggunaan insektisida dengan cara penyemprotan dan larvasida. ${ }^{7,8}$

Mengetahui data tentang kepadatan larva nyamuk merupakan langkah awal pencegahan terhadap dampak buruk akibat serangga (khususnya nyamuk) bagi kesehatan. Data tentang vektor ini dapat diketahui dengan melakukan survei larva. Sehingga dapat menurunkan populasi vektor serendah mungkin sehingga keberadaannya tidak lagi berisiko untuk terjadinya penularan penyakit melalui vektor di suatu wilayah dan menghindari kontak masyarakat dengan vektor sehingga penularan penyakit dapat dicegah. ${ }^{2}$

Berdasarkan uraian diatas bahwa angka kejadian DBD masih sangat tinggi di Kota Padang khususnya Kelurahan Lubuk Buaya sehingga perlu dilakukan pengendalian kepadatan vektor di daerah tersebut. Tetapi pada saat ini pengendalian vektor di daerah ini belum mampu memutus rantai penularan. Oleh karena itu, peneliti tertarik untuk melakukan penelitian di daerah ini untuk mengetahui kepadatan vektor dengan menggunakan survei larva dan hubungannya dengan kejadian DBD di Kelurahan Lubuk Buaya Kecamatan Koto Tangah Kota Padang.

\section{METODE}

Jenis penelitian ini adalah penelitian analitik dengan desain case control. Populasi adalah semua rumah yang terdapat di Kelurahan Lubuk Buaya Kecamatan Koto Tangah Kota Padang dengan jumlah 6383 Kepala Keluarga (KK). Sampel yang memenuhi kriteria inklusi dan ekslusi sebanyak $50 \mathrm{KK}$. Penelitian ini dilaksanakan dari bulan November 2013 sampai 
Desember 2014.Variabel bebas dalam penelitian ini adalah kepadatan larva Aedes spp. dan variabel tergantung adalah kejadian DBD.

Analisis data dilakukan secara bertahap yaitu dengan melakukan analisis univariat serta uji statistik chi-square untuk melihat hubungan kepadatan larva Aedes spp. dengan kejadian DBD di Kelurahan Lubuk Buaya Kecamatan Koto Tangah Kota Padang.

HASIL

\section{Analisis Univariat}

Tabel 1. Distribusi frekuensi keberadaan larva Aedes spp.di Kelurahan Lubuk Buaya Kecamatan Koto Tangah Kota Padang

\begin{tabular}{lcc}
\hline $\begin{array}{l}\text { Keberadaan } \\
\text { Larva }\end{array}$ & $\mathbf{f}$ & $\%$ \\
\hline Ada larva & 26 & 52,0 \\
Tidak ada larva & 24 & 48,0 \\
\hline Total & 50 & 100,0 \\
\hline
\end{tabular}

Berdasarkan Tabel 1 di atas dapat dilihat bahwa dari 50 rumah yang diperiksa, terdapat 26 rumah $(52,0 \%)$ yang ditemukan larva nyamuk dan 24 rumah $(48,0 \%)$ tidak ditemukan larva nyamuk.
Tabel 2. Distribusi frekuensi spesies nyamuk Aedes spp. berdasarkan rumah yang positif larva di Kelurahan Lubuk Buaya Kecamatan Koto Tangah Kota Padang

\begin{tabular}{lcccc}
\hline \multirow{2}{*}{ Jenis Larva } & \multicolumn{2}{c}{ Dalam Rumah } & \multicolumn{2}{c}{ Luar Rumah } \\
\cline { 2 - 5 } & $\mathbf{f}$ & $\mathbf{( \% )}$ & $\mathbf{f}$ & $\mathbf{( \% )}$ \\
\hline Ae. aegypti & 19 & 95,0 & 2 & 28,6 \\
Ae. albopictus & 1 & 5,0 & 5 & 71,4 \\
\hline Total & 20 & 100,0 & 7 & 100,0 \\
\hline
\end{tabular}

Ae.aegypti lebih banyak ditemukan daripada Ae.albopictus. Ae.aegypti lebih banyak ditemukan di dalam rumah sekitar 95,0\%, sedangkan $A e$. albopictuslebih banyak di luar rumah yaitu $71,4 \%$.

Berdasarkan Tabel 3 terlihat bahwa kepadatan vektor DBD di Kelurahan Lubuk Buaya Kecamatan Koto Tangah Kota Padang berdasarkan House Index $(\mathrm{HI})$ yaitu $52,0 \%$ dengan angka tertinggi pada kelompok kasus $(68,0 \%)$ dan terendah pada kelompok kontrol (36,0\%). Angka Container Index (Cl) diperoleh $21,38 \%$, dengan angka tertinggi pada kelompok kasus $(25,58 \%)$ dan angka terendah pada kelompok kontrol $(16,44 \%)$.

Tabel 3. Distribusi frekuensi kepadatan larva vektor DBD berdasarkan House Index (HI), Container Index (CI), dan Breteau Index (BI) di Kelurahan Lubuk Buaya Kecamatan Koto Tangah Kota Padang

\begin{tabular}{|c|c|c|c|c|c|c|c|c|c|c|c|}
\hline DBD & $\begin{array}{l}\text { Jumlah } \\
\text { Rumah }\end{array}$ & $\begin{array}{l}\text { Rumah } \\
\text { (+) Larva }\end{array}$ & $\begin{array}{l}\text { Jumlah } \\
\text { Kontainer }\end{array}$ & $\begin{array}{l}\text { Kontainer } \\
\text { (+) Larva }\end{array}$ & HI (\%) & DF & $\mathrm{Cl}(\%)$ & DF & $\mathrm{BI}(\%)$ & DF & $\begin{array}{l}\text { DF Rata- } \\
\text { rata }\end{array}$ \\
\hline DBD (+) & $25 \mathrm{KK}$ & 17 & 86 & 22 & 68,0 & 8 & 25,58 & 6 & 88,0 & 7 & 7 \\
\hline DBD (-) & $25 \mathrm{KK}$ & 9 & 73 & 12 & 36,0 & 5 & 16,44 & 5 & 48,0 & 5 & 5 \\
\hline \multicolumn{5}{|c|}{ Total } & 52,0 & 7 & 21,38 & 6 & 68,0 & 6 & 6,33 \\
\hline
\end{tabular}

Angka untuk Breteau Index (BI) yaitu 68,0\%, angka tertinggi pada kelompok kasus $(88,0 \%)$ dan angka terendah pada kelompok kontrol $(48,0 \%)$. Angka Density Figure(DF) yang didapatkan di Kelurahan Lubuk Buaya yaitu 6,33, dimana pada kelompok kasus didapatkan kepadatan tinggi sedangkan pada kelompok kontrol kepadatannya sedang.
Tabel 4. Distribusi frekuensi kepadatan larva vektor DBD berdasarkan density figure (DF) di Kelurahan Lubuk Buaya Kecamatan Koto Tangah Kota Padang

\begin{tabular}{lcccc}
\hline \multirow{2}{*}{$\begin{array}{l}\text { Kepadatan } \\
\text { Larva }\end{array}$} & \multicolumn{3}{c}{ Kontrol } & \multicolumn{2}{c}{ Kasus } \\
\cline { 2 - 5 } & f & \% & f & $\%$ \\
\hline $\begin{array}{l}\text { Kepadatan } \\
\text { Ringan }\end{array}$ & 16 & 64,0 & 8 & 32,0 \\
$\begin{array}{l}\text { Kepadatan } \\
\text { Berat }\end{array}$ & 9 & 36,0 & 17 & 68,0 \\
\hline Total & 25 & 100,0 & 25 & 100,0 \\
\hline
\end{tabular}


Pada Tabel 4 dapat dilihat bahwa kepadatan vektor di Kelurahan Lubuk Buaya Kecamatan Koto Tangah Kota Padang berdasarkan Density Figure (DF), didapatkan kepadatan ringan sebesar 24 rumah $(48,0 \%)$ dan kepadatan berat sebesar 26 rumah $(52,0 \%)$.

Tabel 5. Distribusi frekuensi jenis kontainer berdasarkan keberadaan larva vektor DBD di Kelurahan Lubuk Buaya Kecamatan Koto Tangah Kota Padang

\begin{tabular}{|c|c|c|c|c|c|c|c|c|c|}
\hline & \multirow{3}{*}{$\begin{array}{c}\text { Jenis } \\
\text { Kontain€ } \\
r\end{array}$} & \multicolumn{8}{|c|}{ Jumlah Kontainer yang diperiksa } \\
\hline & & \multicolumn{4}{|c|}{ Dalam Rumah } & \multicolumn{4}{|c|}{ Luar Rumah } \\
\hline & & f & $(\%)$ & $\begin{array}{c}\text { Larva } \\
(+)\end{array}$ & (\%) & f & $(\%)$ & $\begin{array}{c}\text { Larva } \\
(+)\end{array}$ & $(\%)$ \\
\hline 1 & $\begin{array}{l}\text { Bak } \\
\text { mandi } \\
\text { semen }\end{array}$ & 12 & 8,6 & 7 & 5,0 & & & & \\
\hline 2 & $\begin{array}{l}\text { Bak } \\
\text { mandi } \\
\text { keramik }\end{array}$ & 15 & 10,8 & 2 & 1,44 & & & & \\
\hline 3 & $\begin{array}{l}\text { Bak } \\
\text { mandi } \\
\text { plastik }\end{array}$ & 8 & 5,76 & 0 & 0,0 & & & & \\
\hline 4 & Dispense & 25 & 18 & 10 & 7,2 & & & & \\
\hline 5 & Kulkas & 41 & 29,5 & 4 & 2,88 & & & & \\
\hline 6 & Drum & 1 & 0,72 & 1 & 0,72 & & & & \\
\hline 7 & $\begin{array}{l}\text { Ember } \\
\text { plastik }\end{array}$ & 37 & 26,62 & 1 & 0,72 & & & & \\
\hline 8 & Drum & & & & & 2 & 10,0 & 1 & 5,0 \\
\hline 9 & $\begin{array}{l}\text { Ember } \\
\text { plastik }\end{array}$ & & & & & 11 & 55,0 & 3 & 15,0 \\
\hline 10 & $\begin{array}{l}\text { Ban } \\
\text { bekas }\end{array}$ & & & & & 2 & 10,0 & 2 & 10,0 \\
\hline 11 & $\begin{array}{l}\text { Kaleng } \\
\text { bekas }\end{array}$ & & & & & 3 & 15,0 & 3 & 15,0 \\
\hline 12 & $\begin{array}{l}\text { Pot } \\
\text { Bunga }\end{array}$ & & & & & 2 & 10,0 & 0 & 0,0 \\
\hline & Total & 139 & 100,0 & 25 & 17,96 & 20 & 100,0 & 9 & 45 \\
\hline
\end{tabular}

Berdasarkan Tabel 5 diketahui bahwa larva Aedes spp. lebih menyukai kontainer yang berada di dalam rumah dibandingkan di luar rumah. Hal ini terlihat dari kontainer di dalam rumah yang positif larva sebanyak 25 kontainer, sedangkan kontainer yang berada di luar rumah yang positif larva sebanyak 9 kontainer. Kontainer di dalam rumah yang terbanyak mengandung larvaAedes spp. adalah dispenser yaitu sebanyak 10 buah $(7,2 \%)$, kemudian diikuti bak mandi semen sebanyak 7 buah (5,0\%). Sedangkan kontainer

di luar rumah yang terbanyak mengandung larva adalah ember plastik dan kaleng bekas yaitu samasama sebanyak 3 buah (15,0\%).

\section{Analisis Bivariat}

Tabel 6. Hubungan kepadatan larva aedes spp. dengan kejadian DBD di Kelurahan Lubuk Buaya Kecamatan Koto Tangah Kota Padang

\begin{tabular}{lccccc}
\hline \multirow{2}{*}{$\begin{array}{l}\text { Kepadatan } \\
\text { Larva }\end{array}$} & \multicolumn{4}{c}{ Kejadian DBD } & \multirow{2}{*}{ Kontrol } \\
\cline { 2 - 4 } & \multicolumn{2}{c}{ Kasus } & \\
\hline $\begin{array}{l}\text { Kepadatan } \\
\text { Ringan }\end{array}$ & 16 & 64,0 & 8 & 32,0 & \\
$\begin{array}{l}\text { Kepadatan } \\
\text { Berat }\end{array}$ & 9 & 36,0 & 17 & 68,0 & 0,048 \\
\hline Total & 25 & 100,0 & 25 & 100,0 & \\
\hline
\end{tabular}

Berdasarkan Tabel 6 diketahui bahwa kelompok kasus yang memiliki kepadatan larva ringan sebanyak 8 orang $(32,0 \%)$, dan kepadatan berat ada 17 orang $(68,0 \%)$. Kelompok kontrol yang memiliki kepadatan ringan sebanyak 16 orang $(64,0 \%)$, dan kepadatan berat 9 orang $(36,0 \%)$. Hasil analisis menggunakan uji chi-square didapatkan nilai $p$ sebesar 0,048 (nilai $p<0,05$ ), yang menunjukkan bahwa kepadatan larva Aedes spp. memiliki hubungan yang bermakna dengan kejadian DBD di Kelurahan Lubuk Buaya Kecamatan Koto Tangah Kota Padang.

\section{PEMBAHASAN}

Penelitian ini dilakukan pada tahun 2014 di Kelurahan Lubuk Buaya Kecamatan Koto Tangah Kota Padang, total sampel adalah 25 KK.

Penelitian terhadap hubungan kepadatan larva Aedes spp. dengan kejadian DBD di Kelurahan Lubuk Buaya Kecamatan Koto Tangah Kota Padang telah dilakukan sesuai dengan prosedur. Prosedur tersebut diantaranya mencari data awal pasien DBD dipuskesmas lubuk buaya, mencari larva nyamuk disetiap kontainer yang ada di rumah sampel, mengeleminasi kriteria eksklusi. 


\section{Keberadaan Larva}

Hasil penelitian menunjukkan bahwa dari 50 rumah yang diperiksa terdapat 26 rumah $(52,0 \%)$ yang ditemukan larva nyamuk dan 24 rumah $(48,0 \%)$ tidak ditemukan larva nyamuk. Berbeda dengan penelitian yang dilakukan di Kelurahan Binjai Kota Medan, dari 100 rumah responden yang diperiksa, terdapat 5 rumah $(5 \%)$ yang setelah kontainernya diperiksa ditemukan larva nyamuk dan terdapat 95 rumah (95\%) yang tidak ditemukan larva nyamuk. ${ }^{9}$

Tempat yang disukai oleh nyamuk vektor DBD ini adalah TPA yang mengandung air jernih, tidak terkena sinar matahari langsung dan nyamuk Ae.aegypti tidak dapat hidup di air yang berhubungan langsung dengan tanah. Dari berbagai TPA, bak mandi merupakan tempat yang paling digemari oleh nyamuk Ae.aegypti. Diduga nyamuk ini menyukai bak mandi karena volumenya yang relatif lebih besar dan paling banyak berada di dalam rumah sehingga cukup kondusif untuk perkembangbiakannya. ${ }^{10}$

Berdasarkan hasil wawancara, kelompok kasus lebih banyak menggunakan ember plastik sebagai tempat penampungan air meskipun mereka memiliki bak mandi. Kontainer seperti ember plastik dengan daya muat sebanyak 50 liter cukup untuk persediaan air 1-2 hari sehingga sering terpakai habis dan tidak bisa dijadikan sebagai tempat perindukan nyamuk. ${ }^{9}$ Kelompok kontrol hampir keseluruhan yang telah menerapkan PSN sehingga breeding place Aedes spp. tersebut terganggu. Oleh karena itu didapatkan selisih keberadaan larva pada penelitian ini selisihnya tidak jauh berbeda antara kelompok kasus dengan kelompok kontrol.

\section{Spesies Nyamuk Aedes spp.}

Hasil penelitian menunjukkan bahwa Ae.aegypti lebih banyak ditemukan daripada Ae.albopictus. Ae.aegypti ditemukan sekitar 95,0\% di dalam rumah dan $28,6 \%$ diluar rumah, sedangkan $A e$. albopictus ditemukan $5,0 \%$ di dalam rumah dan $71,4,0 \%$ ditemukan diluar rumah. Hasil penelitian ini menunjukkan bahwa Ae.aegypti lebih menyukai tempat perindukan di dalam rumah dibandingkan di luar rumah.Sementara itu, Ae.albopictus yang lebih banyak ditemukan di luar rumah lebih menyukai tempat perindukan di luar rumah dibandingkan di dalam rumah.

Hasil penelitian ini hampir sama dengan penelitian yang dilakukan di Kecamatan Baturaja timur, dari 182 kontainer yang diperiksa didapatkan 54 kontainer (31\%) positif larva. Dari 54 larva nyamuk tersebut, larva nyamuk Aedes paling banyak ditemukan yaitu 49 ekor (91\%). Larva nyamuk lainnya adalah Culex yaitu sebanyak 5 ekor (9\%). Dalam penelitian ini Ae.aegypti juga lebih banyak ditemukan dibandingkan dengan Ae.albopictus. ${ }^{11}$

Kebiasaan hidup masing-masing dari spesies Aedes spp. berbeda. Nyamuk Ae. aegypti lebih menyukai tempat di dalam rumah penduduk yaitu hinggap pada pakaian yang digantung untuk beristirahat dan bersembunyi menantikan saat yang tepat untuk mengisap darah inang, sementara $A e$. albopictus lebih menyukai tempat di luar rumah yaitu hidup di pohon atau kebun atau kawasan pinggir hutan. $^{12}$

Nyamuk Ae. aegypti lebih banyak ditemukan berkembang biak di tempat tempat penampungan air buatan seperti bak mandi, ember, vas bunga, tempat minum burung, kaleng bekas, ban bekas dan sejenisnya di dalam rumah meskipun juga ditemukan di luar rumah di wilayah perkotaan. Nyamuk Ae. Aegypti tersebar luas di wilayah tropis dan subtropis Asia Tenggara terutama di perkotaan. Sedangkan Ae. albopictus lebih banyak ditemukan di penampungan air alami di luar rumah, seperti axilla daun, lubang pohon, potongan bambu dan sejenisnya terutama di wilayah pinggiran kota dan pedesaan. ${ }^{7}$ Dalam penelitian ini, larva Ae. aegypti lebih banyak ditemukan dibandingkan Ae. albopictus karena sesuai dengan teori diatas bahwa daerah Kelurahan Lubuk Buaya merupakan wilayah perkotaan.

\section{Kepadatan Larva berdasarkan $\mathrm{HI}, \mathrm{Cl}, \mathrm{BI}$, dan DF}

Hasil penelitian menunjukkan bahwa nilai ratarata House Index (HI) 52\%, Container Index (CI)21,38\% dan Breteau Index (BI) 68,0\% sehingga diperoleh Density Figure (DF) rata-rata adalah 6,33. Hasil ini menunjukkan bahwa kepadatan larva di Kelurahan Lubuk Buaya Kecamatan Koto Tangah Kota Padang tinggi sehingga beresiko untuk penularan 
penyakit DBD. Sedangkan kepadatan vektor di Kelurahan Lubuk Buaya Kecamatan Koto Tangah Kota Padang berdasarkan Density Figure (DF), didapatkan kepadatan ringan sebesar 24 rumah $(48,0 \%)$ dan kepadatan berat sebesar 26 rumah (52,0\%). Menurut Kantachuvessir dalam Zulkarnaini, suatu wilayah dikatakan risiko tinggi untuk penularan DBD jika Container Index $(\mathrm{Cl}) \geq 5 \%$, dan House Index $(\mathrm{HI}) \geq 10 \%$. Berdasarkan ketentuan tersebut, kepadatan dan penyebaran vektor DBD di Kelurahan Lubuk Buaya tergolong tinggi.Breteau Index (BI) merupakan prediktor $\mathrm{KLB}$, jika $\mathrm{BI} \geq 50$ maka daerah tersebut berpotensi untuk mengalami KLB. Dari penelitian ini didapatkan $\mathrm{BI}=68,0 \%$, sehingga dapat dimengerti jika di Kelurahan Lubuk Buaya terjadi KLB. ${ }^{13}$

Menurut WHO (2005), indikator adanya ancaman wabah DBD adalah apabila terdapat daerah dengan Density Figure (DF) diatas 5, ini berarti besar sekali kemungkinan terjadinya transmisi penyakit DBD, sedangkan apabila Density Figure(DF) $1-5$, maka kemungkinan transmisi penyakit DBD dianggap rendah hingga sedang. Berdasarkan hal diatas, Lubuk Buaya memiliki kemungkinan tranmisi penyakit DBD yang besar karena angka Density Figure (DF) adalah $6,33 .^{1}$

\section{Jenis Kontainer berdasarkan Kepadatan Larva Aedes spp.}

Penelitian ini menunjukkan bahwa larva Aedes spp. lebih menyukai kontainer yang berada di dalam rumah dibandingkan di luar rumah. Hal ini terlihat dari kontainer di dalam rumah yang positif larva sebanyak 25 kontainer, sedangkan kontainer yang berada di luar rumah yang positif larva sebanyak 9 kontainer. Selain itu, juga diketahui bahwa kontainer di dalam rumah yang terbanyak mengandung larvaAedes spp. adalah dispenser yaitu sebanyak 10 buah $(7,2 \%)$, kemudian diikuti bak mandi semen sebanyak 7 buah (5,0\%). Sedangkan kontainer di luar rumah yang terbanyak mengandung larva adalah ember plastik dan kaleng bekas yaitu sama-sama sebanyak 3 buah $(15,0 \%)$.

Nyamuk Aedes spp. betina lebih menyukai tempat air yang tertutup longgar sebagai tempat bertelur dibandingkan tempat air yang terbuka. Karena ruangan di tempat air yang tertutup longgar mengakibatkan ruangan di dalamnya lebih gelap dibandingkan tempat air yang terbuka. ${ }^{10}$

Besarnya kontainer dan lamanya air yang disimpan di dalamnya menyebabkan banyak nyamuk yang bisa bertelur disana, seperti bak mandi semen dengan kapasitas 200 liter menyebabkan airnya jarang bertukar. Nyamuk betina juga lebih suka bertelur pada habitat dengan permukaan kasar, berwarna kelabu, dan berefleksi rendah daripada permukaan licin, hitam, dan berefleksi tinggi. ${ }^{10}$ Warna gelap dapat memberikan rasa aman dan tenang bagi nyamuk Aedes spp. pada saat bertelur, sehingga telur yang diletakkan dalam TPA lebih banyak. ${ }^{11}$

Ember dan kaleng bekas yang dibiarkan di halaman dan tidak dikuburkan atau di simpan disukai nyamuk Aedesspp .sebagai tempat perindukannya karena air dalam ember dan kaleng bekas tidak dibuang dan tidak diperhatikan. Terlihat bahwa perindukan non TPA memiliki nilai total lebih tinggi dibandingkan dari perindukan TPA, hal ini disebabkan karena barang bekas kebanyakan diletakan di luar rumah dan halaman sehingga kurang di perhatikan kebersihannya dan jika dibiarkan tertampung air, baik air hujan, sumur atau PAM, maka air yang diam didalamnya tidak digunakan sehingga dijadikan tempat bertelur oleh nyamuk Ae. aegypti, hal ini sesuai dengan pola bertelur Ae. aegypti yang suka bertelur pada air yang tersimpan lama serta tidak dipakai. ${ }^{11}$

\section{Hubungan Kepadatan Larva Aedes spp. dengan Kejadian DBD}

Hubungan bermakna antara kepadatan larva Aedes spp. dengan kejadian DBD begitu juga dengan penelitian Parida. Hasil analisis menggunakan uji Exact Fisher diperoleh nilai $p$ sebesar 0,002 (nilai $p$ $<0,005$ ), yang berarti bahwa keberadaan larva memiliki hubungan yang bermakna dengan terjadinya penyakit DBD. ${ }^{9}$

Faktor yang berhubungan dengan penyakit Demam Berdarah Dengue adalah faktor host, faktor lingkungan, dan faktor perilaku. Salah satu faktor lingkungan yang sangat mempengaruhi penyakit DBD adalah kepadatan nyamuk dan tempat perindukan. Semakin tinggi kepadatan nyamuk maka akan semakin besar kemungkinan manusia di sekitarnya 
untuk dihisap darahnya yang diperlukan oleh nyamuk tersebut untuk mematangkan telurnya. ${ }^{14}$

Tingginya kejadian DBD di Kelurahan Lubuk Buaya ini diduga karena perilaku tidur siang dan kebiasaan menggantung pakaian. Kebiasaan tidur siang ini berkaitan dengan aktivitas menggigit nyamuk yaitu pada pukul 09.00-10.00 dan 16.00-17.00. Jika ada dari kelompok sampel yang tidur siang pukul 16.00-17.00 tanpa menggunakan repellent dan digigit nyamuk yang menggandung virus dengue maka akan menyebabkan orang tersebut akan terkena penyakit DBD. Kebiasaan menggantung pakaian di dalam rumah juga berpengaruh terhadap tingginya kejadian DBD karena pakaian yang digantung tersebut akan menjadi tempat beristirahat dan bersembunyi bagi nyamuk untuk menantikan saat yang tepat agar dapat menghisap darah inangnya. ${ }^{15}$

Kejadian DBD juga dipengaruhi oleh cara penularan secara transovarian. Telur nyamuk yang berasal dari nyamuk yang terinfeksi virus dengue akanmenjadi nyamuk terinfeksi yang dapat menularkan virus dengue kepada inangnya yaitu manusia. ${ }^{15}$ Oleh karena itu sangat dikhawatirkan kejadian DBD akan terjadi secara terus-menerus meskipun faktor host, faktor lingkungan, dan faktor perilaku sudah diperbaiki.

Pengendalian DBD sekarang hanya menitikberatkan pada pengendalian lingkungan untuk memutus transmisi atau penularan dengan cara Pemberantasan Sarang Nyamuk (pengendalian tempat perindukan nyamuk) dan fogging. Selain itu, kegiatan utama lainnya adalah penyuluhan untuk mendapatkan perubahan perilaku positif dalam rangka pengendalian tempat perindukan maupun upaya pengendalian faktor risiko lainnya. ${ }^{16}$

Penyuluhan juga sangat penting dilakukan untuk pengendalian penyakit DBD tetapi penyuluhan yang dilakukan oleh puskesmas Lubuk Buaya dapat dikatakan kurang, karena program penyuluhan di puskesmas ini dalam 1 bulan sebanyak 8 kali. Dalam 8 kali penyuluhan itu tidak hanya tentang DBD tetapi juga penyakit lainnya sehingga untuk penyakit DBD penyuluhannya hanya sebanyak 7 kali dalam tahun 2014.Selain itu penyuluhan ini dilakukan di dalam gedung di RW/RT tertentu sehingga tidak mencakup seluruh warga.

\section{SIMPULAN}

Ditemukan lebih banyak rumah dengan positif larva dibandingkan rumah yang negatif larva. Distribusi spesies larva yang ditemukan di Kelurahan Lubuk Buaya Kecamatan Koto Tangah Kota Padang adalah Ae. aegypti lebih banyak ditemukan daripada Ae. albopictus.

Kepadatan larva vektor DBD di Kelurahan Lubuk Buaya Kecamatan Koto Tangah Kota Padang termasuk resiko tinggi penularan DBD dan berpotensi menimbulkan KLB. Kontainer di dalam rumah dan positif jentik terbanyak adalah dispenser, sedangkan kontainer di luar rumah dan positif jentik terbanyak adalah ember plastik dan kaleng bekas. Terdapat hubungan yang bermakna antara kepadatan larva Aedes spp. dengan kejadian DBD di Kelurahan Lubuk Buaya Kecamatan Koto Tangah Kota Padang.

\section{DAFTAR PUSTAKA}

1. WHO: Panduan lengkap pencegahan \& pengendalian dengue \& demam berdarah dengue. Jakarta: EGC; 2005: 1-101.

2. Kementerian Kesehatan Republik Indonesia: Pengendalian vektor. Jakarta: Kementerian Kesehatan RI; 2010.

3. Kantor Wilayah Departemen Kesehatan Provinsi Sumatera Barat. Insiden demam berdarah dengue di Provinsi Sumatera Barat. Padang: Departemen Kesehatan Provinsi Sumatera Barat; 2012.

4. Departemen Kesehatan Kota Padang. Insiden demam berdarah dengue di Kota Padang. Padang: Departemen Kesehatan Kota Padang; 2013.

5. Hasyimi. Pengamatan tempat perindukan Ae. aegypti pada tempat penampungan air rumah tangga pada masyarakat pengguna air olahan. Jakarta: Jurnal Ekologi Kesehatan; 2004;4(3):3742.

6. Adrial. Beberapa indikator entomologi nyamuk. Padang: Majalah Kedokteran Andalas; 2006; 2(2): 60-8.

7. Sukowati S. Masalah vektor DBD dan pengendaliannya di Indonesia. Jakarta: Buletin Jendela Epidemiologi; 2010; 2(4): 26-30.

8. Kementerian Kesehatan Republik Indonesia. Modul pengendalian demam berdarah dengue. Jakarta: Kementerian Kesehatan RI; 2011. 
9. Parida S. Hubungan keberadaan jentik Aedes aegypti dan pelaksanaan $3 \mathrm{M}$ plus dengan kejadian DBD di lingkungan XVIII Kelurahan Binjai Kota Medan tahun 2012 (skripsi). Medan: Program Studi IImu Kesehatan Masyarakat Fakultas Kesehatan Masyarakat Universitas Sumatera Utara; 2012.

10. Sunaryo, Sumarno PS. Demam berdarah (dengue) pada anak. Jakarta: UI-Press; 2005.

11. Anif B.Karakteristik kontainer terhadap keberadaan jenis Aedes Aegypti di sekolah dasar. Jurnal Pembangunan Manusia; 2012; 6(1): 1-9.

12. Kemenkes Kesehatan Republik Indonesia. Modul pelatihan bagi pelatih pemberantasan sarang nyamuk demam berdarah dengue (PSN-DBD) dengan pendekatan komunikasi perubahan perilaku. Jakarta:Kementerian Kesehatan RI; 2008.
13. Zulkarnaini. Hubungan kondisi sanitasi lingkungan rumah tangga dengan keberadaan jentik vektor demam berdarah dengue. urnal Environmental; 2009; 2(3): 115-124.

14. Wahyono, Haryanto, Mulyono, Adiwibowo. Faktorfaktor yang berhubungan dengan kejadian demam berdarah dan upaya penanggulangannya. Jakarta: Buletin Jendela Epidemiologi. 2010; 2(5);31-43.

15. Supharta IW. Pengendalian terpadu vektor virus demam berdarah dengue, Aedes aegypti dan Aedes albopictus. Denpasar: Dies Natalis Universitas Udayana; 2008;1-15.

16. Achmadi. Manajemen DBD berbasis wilayah. Jakarta: Buletin Jendela Epidemiologi; 2010; 2(1) : 15-19. 